\title{
f criação e gestão de miniempresas na sala de aula: opiniões dos alunos e professores participantes do Programa Empreender na Escola
}

\section{Creation and Management of Pupil Enterprises: Opinions of Participating Students and Teachers on the Entrepreneurship in the School Program \\ Creación y gestión de microempresas en el salón de clase: opiniones de estudiantes y profesores participantes en el Programa Emprender en la Escuela}

\author{
*Susana Imaginário, "Eurídice Cristo, "Saul Neves de Jesus, ${ }^{* *}$ Fátima Morais \\ *Universidade do Algarve, Faro, Portugal. \\ ${ }^{* *}$ Universidade do Minho, Braga, Portugal.
}

Doi: http://dx.doi.org/10.12804/revistas.urosario.edu.co/ap1/a.3710

\section{Resumo}

O Programa Empreender na Escola é um programa de educação que visa a promoção do desenvolvimento de competências na área do empreendedorismo através da criação e gestão, por parte dos alunos, de miniempresas de "importação/exportação" que funcionam em parcerias comerciais, trocando entre si produtos que serão posteriormente comercializados na comunidade local. Realizado no âmbito do Programa Estratégico da "Rede de Cidades e Centros Urbanos para a Competitividade e a Inovação do Corredor Azul" foi implementado em 12 escolas de 7 municípios da região do Alentejo, Portugal, envolvendo 281 alunos e 27 professores do ensino básico e secundário, organizados em 18 "empresas" e 9 parcerias comerciais. Recorrendo a uma amostra aleatória de alunos e professores participantes procurámos conhecer a sua opinião sobre o desenvolvimento do projeto e sobre a sua participação através de um questionário desenvolvido para o efeito. Os resultados demonstraram que o estabelecimento de relações interpessoais é um aspeto muito importante para os participantes e que deve ser mantido e fomentado em programas deste género. Além disso, deve existir também uma redução da carga burocrática para que no final do $1^{\circ}$ período as miniempresas já estejam em condições de comercializar os produtos "importados" da "empresa" parceira.

Palavras-chave: educação para o empreendedorismo; programa de promoção do empreendedorismo; gestão de miniempresas na sala de aula; estudantes e professores do ensino básico e secundário.

* Susana Imaginário, Saúl Neves de Jesus, Faculdade de Ciências Humanas e Sociais, Universidade do Algarve, Faro, Portugal, Eurídice Cristo, Divisão de Empreendedorismo e Transferência de Tecnologia (CRIA), Universidade do Algarve, Faro, Portugal; **Fátima Morais, Instituto de Educação, Universidade do Minho, Braga, Portugal.

Correspondência a respeito deste artigo deve ser endereçada para Susana Imaginário, CIEO, Campus de Gambelas ed 9, Universidade do Algarve, 8005-139, Gambelas-Faro, Portugal. Correio eletrônico: ssimaginario@ualg.pt

Cómo citar este artículo: Imaginário, S., Cristo, E., Neves de Jesus, S., \& Morais, F. (2017). A criação e gestão de miniempresas na sala de aula: opiniões dos alunos e professores participantes do Programa Empreender na Escola. Avances en Psicología Latinoamericana, 35(1), 23-42. doi: http://dx.doi.org/10.12804/revistas.urosario.edu.co/apl/a.3710 


\section{fibstract}

The Entrepreneurship in the School Program is an educational program aiming to promote the development of skills in the area of entrepreneurship through the creation and management of "Import/Export" pupil enterprises, operating in commercial partnerships and exchanging products that later were sold in the local community. Conducted under the Strategic Program of "Network of Cities and Urban Competitiveness and Innovation of the Blue Corridor" it was implemented in 12 schools in 7 counties of the Alentejo region, Portugal, involving 281 students and 27 teachers from the primary and secondary education levels, organized into 18 pupil enterprises and 9 commercial partnerships. Using a random sample of participants including students and teachers, we aimed to know their opinion about the development of the project, as well as their views of their participation using a questionnaire developed for the purpose. The results demonstrated that the establishment of interpersonal relationships was very important to the participants and should be maintained and encouraged in similar programs in the future. In addition, the bureaucracy of the Program should be reduced, allowing the pupil enterprises to start selling their "imported" products earlier. Keywords: entrepreneurship education; program to promote entrepreneurship; pupil enterprises management; primary and secondary's education students and teachers.

\section{Resumen}

El Programa Empreender na Escola (Programa Emprender en la Escuela) es un programa de educación que busca la promoción del desarrollo de competencias en el área del emprendimiento a través de la creación y gestión, por parte de los alumnos, de microempresas de "importación/exportación" que funcionan en alianzas comerciales, intercambiando productos entre sí que serán posteriormente comercializados en la comunidad local. Realizado en el ámbito del Programa Estratégico de la "Red de Ciudades y Centros Urbanos para la Competitividad y la Innovación del Corredor Azul", fue implementado en 12 escuelas de 7 municipios de la región de Alentejo, en Portugal, involucrando 281 alumnos y 27 profesores de primaria y bachillerato, organizados en 18 "empresas" y 9 alianzas comerciales. Recurriendo a una muestra aleatoria de alumnos y profesores participantes, buscamos conocer su opinión sobre el desarrollo del proyecto y sobre su participación a través de un cuestionario desarrollado para tal efecto. Los resultados demostraron que el establecimiento de relaciones interpersonales es un aspecto muy importante para los participantes y que debe ser mantenido y fomentado en programas de este género. Además, debe existir también una reducción de carga burocrática para que al final del primer trimestre las microempresas ya estén en condiciones de comercializar los productos "importados" de la "empresa" aliada.

Palabras clave: educación para el emprendimiento; programa de promoción del emprendimiento; gestión de microempresas en el salón de clases; estudiantes y profesores de primaria y bachillerato.

\section{Introdução}

As primeiras definições de empreendedor e de empreendedorismo remontam ao século XVIII (Sorensen \& Chang, 2006, citado por Mendes, 2007), mas apenas nos últimos 50 anos este conceito tem vindo a ganhar importância, sendo objeto de estudo de várias disciplinas científicas (Cunnignham \& Lischeron, 1991), o que dificulta a sua definição. Embora a sua conceptualização esteja sobretudo focada na criação e gestão de empresas, recentemente tem-se chamado a atenção para o intraempreendedorismo, referindo-se aos profissionais que, não possuindo o seu próprio negócio, assumem atitudes empreendedoras no seu local de trabalho (Mendes, 2007).

Um empreendedor caracteriza-se por ter visão, capacidade de adaptação e de persuasão, ser capaz de assumir riscos, ser honesto, perseverante, disciplinado, organizado, competitivo e compreensivo (National Commission on Entrepreneurship, 2003, 
citado por Moreland, 2006). A estas competências e características, Faria (2010) acrescenta altruísmo, ponderação, trabalho, realização profissional, empenho e auto-motivação. Já um intraempreendedor pode ser descrito por ter iniciativa, trabalhar independentemente, trabalhar em equipa, trabalhar sob pressão, ter competências de comunicação, de gestão do tempo e de adaptabilidade, prestar atenção aos detalhes, assumir responsabilidades/ decisões, planear, coordenar e organizar, desenvolver o empreendimento e possuir conhecimentos técnicos (Faria, 2010; Moreland, 2006). Várias destas características são também atribuídas a conceitos como criatividade e inovação (Cropley, 2009; Runco, 2007), que são identificados como requisitos fundamentais para o século XXI (Csikszentmihalyi, 2006; MacLaren, 2012).

\section{Educação para o empreendedorismo}

Fomentar o desenvolvimento e a aquisição de atitudes empreendedoras é uma das prioridades de vários países europeus, tendo estas competências sido identificadas como aptidões-chave pela Comissão Europeia (2002). Neste sentido, torna-se essencial sensibilizar as escolas, de todos os níveis de ensino, para a educação para o empreendedorismo, devendo estas contar com o apoio ativo de organizações e entidades de diferentes setores, incluindo o Estado, a sociedade civil e as entidades privadas (Redford, 2006).

Atendendo às diferentes características da população estudantil, não só ao nível da sua idade, mas também do seu desenvolvimento psicossocial, é fundamental que as iniciativas de educação para o empreendedorismo implementadas estejam adaptadas à faixa etária em questão. A este respeito, a Comissão Europeia (2002) defende que no ensino básico, a educação para o empreendedorismo deve centrar-se na promoção de determinadas competências, nomeadamente criatividade, espírito de iniciativa e de independência, assim como proporcionar o contacto dos estudantes com o mundo empresarial, permitindo que adquiram alguns conhecimentos gerais sobre esta área. Já no ensino secundário, o foco da educação para o empreendedorismo deve ser, não só o desenvolvimento de competências e a aquisição de conhecimentos, tal como no nível de ensino anterior, mas também incluir a aprendizagem de conhecimentos mais aprofundados sobre a transição do mundo escolar para o mercado de trabalho e a criação do próprio emprego. Por último, ao nível do ensino superior, universitário ou politécnico, a educação para o empreendedorismo deve visar a aquisição de competências mais específicas sobre a criação e gestão de empresas, incluindo domínios-chave como a identificação de oportunidades de negócios, o desenvolvimento de ideias de negócios e a elaboração de um plano de negócios.

No nosso país, as iniciativas de educação para o empreendedorismo são relativamente recentes. Aliás, em 2002, no Final Report of the Expert Group "Best Procedure" Project on Education and Training for Entrepreneurship (Comissão Europeia, 2002), Portugal foi apontado como o único país europeu onde eram desenvolvidas ações que tinham como objetivo fomentar o espírito empresarial (seminários, conferências e visitas), mas que não estavam incluídas no quadro do sistema nacional de educação. Sobre este assunto, importa ainda referir que $41 \%$ das 17 disciplinas de empreendedorismo lecionadas nas universidades portuguesas, no ano letivo de 2004/2005 tiveram o seu início entre 2003 e 2004 (Redford, 2013).

Em 2006, surge o primeiro programa de educação para o empreendedorismo, concebido e implementado sob a responsabilidade da Direção-Geral de Inovação e Desenvolvimento Curricular do Ministério da Educação, denominado PNEE, Plano Nacional de Educação para o Empreendedorismo (Teixeira, 2012). O PNEE tinha como objetivo promover ações empreendedoras na escola, nomeadamente "projetos de investigação e de intervenção desenvolvidos por alunos dos ensinos básicos e secundário no âmbito das áreas curriculares que 
originem produtos sociais concretos, motivantes, capazes de responder aos seus próprios problemas e necessidades e com um impacto (observável, qualificável ou quantificável) no grupo-turma, na comunidade escolar, local ou regional, orientados para fins sociais, de investigação ou científico-tecnológicos" (Ministério da Educação, 2007, p. 10). Este projeto foi implementado, pela primeira vez, no ano letivo de 2006/2007. Nesta fase piloto, foram convidados a participar 23 estabelecimentos de ensino do segundo e terceiro ciclos e do ensino secundário. Devido aos bons resultados obtidos na sua implementação, foi aprovada a sua prossecução durante mais três anos letivos (2007/2010), integrando também escolas do primeiro ciclo e escolas profissionais (Teixeira, 2012).

Outros programas têm vindo a ser desenvolvidos nos últimos anos, por exemplo o Projeto ENE - Empreender na Escola (CPINAL, 2002), o Empresários na Escola - Percursos de Acompanhamento à Criação de Novas Empresas de Base Tecnológica (Parkurbis, 2007) e o Programa Empreendedorismo na Escola (Rodrigues, Dinis, Paço, Ferreira, \& Raposo, 2012). O ENE foi implementado entre 2002 e 2004, em 10 escolas do ensino secundário da região do Algarve e tinha como objetivo a elaboração de um plano de negócios (CPINAL, 2002). Já o Projeto Empresários na Escola (Parkurbis, 2007) visou o desenvolvimento de capacidades empreendedoras de jovens entre os 13 e os 16 anos $\left(7^{\circ} / 9^{\circ}\right.$ ano de escolaridade) de uma escola secundária da região de Coimbra através da constituição de uma empresa na sala de aula, tendo por base o projeto EJE - Empresa Joven Europea, desenvolvido e implementado na região das Astúrias desde o ano letivo de 1999/2000. Por seu lado, o Programa Empreendedorismo na Escola (Rodrigues et al., 2012) foi implementado no ano letivo de 2011/2012, na Escola Secundária de Estarreja, e compilava uma série de atividades de promoção do empreendedorismo que culminavam com o desenvolvimento de um concurso de ideias para jovens do ensino secundário.
Embora seja possível identificar atividades de promoção do empreendedorismo a nível escolar, muitos dos programas implementados não apresentam um processo de avaliação ao longo do seu desenvolvimento (Garavan \& O'Cinneide, 1994), pelo que nem sempre é possível saber se os objetivos definidos foram alcançados. Além disso, nas análises existentes, os resultados não são consensuais, sendo de sublinhar que a maior parte dos estudos de impacto não incluem pré e pós-teste ou grupo de controlo (Graevenitz, Harhoff, \& Weber, 2010; Matin, McNally, \& Kay, 2013).

Por exemplo, no Relatório Síntese do Plano Nacional de Educação para o Empreendedorismo (Direção-Geral de Inovação e Desenvolvimento Curricular do Ministério da Educação, 2009) verificou-se o desenvolvimento de competências empreendedoras-chave nos alunos participantes, nomeadamente autoconfiança/assunção de risco, iniciativa/energia, planeamento/organização, resistência à frustração/resistência, criatividade/inovação e relações interpessoais/comunicação. Em contrapartida, na implementação do projeto EJE (Parkurbis, 2007) observou-se que os resultados obtidos não refletiam a existência de um impacto positivo da participação no programa na intensão empreendedora dos estudantes, assim como não demonstraram um resultado favorável ao desenvolvimento de uma atitude empreendedora, tendo sido apenas observadas diferenças estatisticamente significativas ao nível da assunção de risco, que diminuiu com a participação.

\section{O Programa Empreender na Escola}

Procurando desenvolver as competências empreendedoras de toda a comunidade educativa, tornando-a mais proativa, autónoma, responsável, autoconfiante, com espírito de equipa, capaz de assumir riscos e preparada para tomar decisões criou-se o Programa Empreender na Escola, destinado a alunos do $9^{\circ}$ ano do ensino básico e do ensino secundário (Imaginário, Cristo, Jesus, \& 
Morais, 2014). Desenvolvido no âmbito do Programa Estratégico da "Rede de Cidades e Centros Urbanos para a Competitividade e a Inovação do Corredor Azul", foi proposto para candidatura ao Eixo 2 do InAlentejo, que abrange dez municípios da região do Alentejo (Sines, Santiago do Cacém, Vendas Novas, Montemor-o-Novo, Évora, Arraiolos, Estremoz, Borba, Vila Viçosa e Elvas) e teve a sua coordenação e implementação a cargo do Sines Tecnopolo, sendo Sines o município líder. Este Programa contou com o apoio técnico-científico da Universidade do Algarve, através da Divisão de Empreendedorismo e Transferência de Tecnologia (CRIA), e com o aval da DGEstE-Alentejo (Direção-Geral de Estabelecimentos Escolares, Direção de Serviços da Região do Alentejo).

O Programa Empreender na Escola baseou-se num método de ensino inovador (Chong et al., 2008) e numa abordagem por competências (Chaves \& Parente, 2011), tal como se observa noutros programas de educação para o empreendedorismo (por exemplo Direção-Geral de Inovação e Desenvolvimento Curricular do Ministério da Educação, 2009; Parkurbis, 2007). Assim sendo, de acordo com esta metodologia de aprendizagem inovadora, a promoção do desenvolvimento de competências empreendedoras é associada à transmissão de conteúdos teóricos através da implementação de projetos desenvolvidos em contexto de sala de aula (Chong et al., 2008), o que pressupõe um envolvimento ativo de escolas e professores; a colocação do aluno em primeiro lugar, enquanto o professor desempenha o papel de orientador (Chaves \& Parente, 2011); e o recurso a métodos eletrónicos e às novas tecnologias de informação para a disseminação dos conhecimentos teórico-práticos (Chong et al., 2008).

Este projeto procurou assim aproximar-se de outros anteriormente implementados e que podem ser considerados como boas práticas, tais como o programa Empreendedorismo nas Escolas (Rocha, Silva, \& Simões, 2012); o programa A Empresa (Chaves \& Parente, 2011); o Plano Nacional de
Educação para o Empreendedorismo (DireçãoGeral de Inovação e Desenvolvimento Curricular do Ministério da Educação, 2009); e o programa EJE, implementado com sucesso em Espanha desde 1999 (Parkurbis, 2007). À semelhança do que acontece nos projetos A Empresa (Chaves \& Parente, 2011) e EJE (Parkurbis, 2007), o Programa Empreender na Escola (Imaginário et al., 2014) pressupunha a criação de uma "empresa" de "importação/exportação", gerida pelos alunos em sala de aula, durante um ano letivo. É de notar que os sócios empresariais, alunos membros de cada miniempresa, realizavam negócios reais com dinheiro real, estabelecendo relações comerciais com outra "empresa", através da troca, entre si, de produtos que posteriormente seriam comercializados para a comunidade local, procurando obter o máximo de lucro possível. As parcerias comerciais estabelecidas foram definidas com base em critérios geográficos e sociodemográficos, por outras palavras, as miniempresas foram emparelhadas tendo em conta o seu afastamento geográfico e a heterogeneidade de características sociodemográficas (média de idades, tipo de ensino e ano frequentado).

A constituição da miniempresa não é formalmente realizada, mas todo o seu processo de criação e gestão é replicado e simulado na íntegra. Com base nesta metodologia, o programa encontra-se estruturado em 3 blocos que correspondem diretamente aos três períodos letivos e remetem para a atividade de uma empresa real (Bloco 1 Constituição da Empresa; Bloco 2 - Organização e Planeamento da Empresa; Bloco 3 - Execução da Empresa e Balanço Final) (Imaginário et al., 2014). Na Constituição da Empresa começa por ser pedido aos alunos que aprofundem o seu conhecimento sobre o seu próprio concelho e sobre o concelho da empresa parceira. Posteriormente organizam formalmente a sua empresa através da escolha do nome da "empresa", da criação a sua imagem corporativa e da distribuição dos recursos humanos pelas diferentes unidades funcionais (direção, marketing e publicidade, comércio externo e 
administração e finanças), entre outros. No Bloco 2 os sócios empresariais escolhem os produtos que irão "exportar" para a "empresa" parceira e os que irão "importar", iniciando ainda as atividades por unidades funcionais, procedendo, por exemplo, à elaboração de um plano de negócios, à criação de um catálogo de produtos, à definição da estratégia de vendas a adotar e ao desenvolvimento da documentação empresarial. No último bloco, dá-se início à venda dos produtos "importados" na comunidade local e encerra-se o ano letivo com produção de um relatório sobre o encerramento de contas.

No desenho deste projeto (Imaginário et al., 2014) procurou-se reproduzir o mais fielmente a realidade empresarial e empreendedora da criação e gestão de empresas, pelo que para além de se basear nas boas práticas identificadas, contou-se ainda com a participação de especialistas de diversas áreas, nomeadamente psicologia, geografia, gestão, economia, criação de empresas e direito. Por outro lado, tendo em conta as mudanças curriculares observadas no sistema educativo, por exemplo, a eliminação da Área de Projeto no ano letivo de 2011/2012, disciplina privilegiada para a implementação de projetos deste género, recorreu-se também ao contributo de professores para a calendarização das atividades e para a adequação dos conteúdos programáticos aos currículos académicos das disciplinas lecionadas no $9^{\circ}$ ano e no ensino secundário.

Este projeto apresenta uma inovação face aos programas existentes: a possibilidade das miniempresas criadas poderem ser apadrinhadas por uma empresa real do seu concelho (a denominada Empresa Mentora). Esta empresa poderia assumir uma multiplicidade de funções, podendo, por exemplo, ajudar na realização das atividades empresariais ou partilhar as suas experiências no mundo empresarial (Imaginário et al., 2014).

Para auxiliar e estruturar a implementação do programa, foram disponibilizados vários materiais que procuravam ainda dar independência à atividade de cada uma das "empresas", nomeadamente o "Manual do aluno" (Cristo, Imaginário,
\& Cruz, 2012a) e o "Manual do professor" (Cristo, Imaginário, \& Cruz, 2012b). Além disso, foi ainda desenvolvida uma plataforma multimédia que permitia a elaboração de toda a documentação empresarial das "empresas" e uma página de Facebook do Programa, onde todos os participantes podiam comunicar entre si (Cristo et al., 2012a, 2012b).

Atendendo à importância que se pretendia que os professores desempenhassem neste projeto foi-lhes oferecida a possibilidade de participarem numa formação certificada pelo Conselho Científico-Pedagógico de Formação Contínua, procurando dotá-los de conhecimentos técnicos da área empreendedora que lhes facilitariam a orientação dos jovens empresários. Esta formação tinha um caráter voluntário e seria complementada com monitorização e aconselhamento, por parte da equipa técnica, a todos os intervenientes de forma presencial (sessões mensais em todas as escolas) e virtual, através de correio eletrónico e de chat da página de Facebook do Programa (Imaginário et al., 2014).

O Programa Empreender na Escola foi então implementado, durante o ano letivo de 2012/2013, em 12 escolas de 7 municípios do território do Corredor Azul (Sines, Santiago do Cacém, Vendas Novas, Montemor-o-Novo, Évora, Vila Viçosa e Elvas), contando com a participação de 281 alunos e 27 professores, organizados em 18 "empresas" e 9 parcerias comerciais. Na tabela 1 são apresentadas, mais detalhadamente, as características dos

Tabela 1

Características dos participantes do Programa Empreender na Escola

\begin{tabular}{lccccc}
\hline \multirow{2}{*}{ Município } & \multicolumn{2}{c}{ Alunos } & \multicolumn{2}{c}{ Professores } \\
\cline { 2 - 5 } & $N^{\circ}$ & Ano & Curso & $N^{\text {No }}$ & $\begin{array}{c}\text { Área de } \\
\text { Formação }\end{array}$ \\
\hline \multirow{2}{*}{ Sines } & 25 & $10^{\circ}$ & $\begin{array}{l}\text { Informática de } \\
\text { Gestão }\end{array}$ & 1 & $\begin{array}{l}\text { Ciências } \\
\text { Socioeconó- } \\
\text { micas }\end{array}$ \\
\cline { 2 - 5 } & 27 & $9^{\circ}$ & Ensino regular & 1 & Geografia \\
\hline
\end{tabular}




\begin{tabular}{|c|c|c|c|c|c|}
\hline \multirow[b]{2}{*}{ Município } & \multicolumn{3}{|c|}{ Alunos } & \multicolumn{2}{|r|}{ Professores } \\
\hline & $\mathrm{N}^{\mathrm{o}}$ & Ano & Curso & $\mathrm{N}^{\mathrm{o}}$ & $\begin{array}{c}\text { Área de } \\
\text { Formação }\end{array}$ \\
\hline \multirow{4}{*}{$\begin{array}{l}\text { Santiago } \\
\text { do Cacém }\end{array}$} & 10 & $9^{\circ}$ & $\begin{array}{l}\text { Clube com alu- } \\
\text { nos de várias } \\
\text { turmas }\end{array}$ & & \multirow{2}{*}{$\begin{array}{l}\text { Educação } \\
\text { Física }\end{array}$} \\
\hline & 12 & $10^{\circ}$ & $\begin{array}{l}\text { Clube com alu- } \\
\text { nos de várias } \\
\text { turmas }\end{array}$ & & \\
\hline & 18 & $\begin{array}{l}9^{\circ} \mathrm{e} \\
11^{\circ}\end{array}$ & $\begin{array}{l}\text { Técnico } \\
\text { Comercial e } \\
\text { Técnico de } \\
\text { Informática }\end{array}$ & 6 & $\begin{array}{l}\text { Ciências } \\
\text { Socioeconó- } \\
\text { micas e Infor- } \\
\text { mática }\end{array}$ \\
\hline & 6 & $9^{\circ}$ & PIEF & 3 & $\begin{array}{l}\text { Matemática, } \\
\text { Ciências Na- } \\
\text { turais e Ação } \\
\text { Social }\end{array}$ \\
\hline \multirow{2}{*}{$\begin{array}{l}\text { Vendas } \\
\text { Novas }\end{array}$} & 16 & $11^{\circ}$ & $\begin{array}{l}\text { Produção Agrí- } \\
\text { cola }\end{array}$ & \multirow{2}{*}{2} & \multirow{2}{*}{ Agricultura } \\
\hline & 22 & $12^{\circ}$ & $\begin{array}{l}\text { Produção Agrí- } \\
\text { cola }\end{array}$ & & \\
\hline $\begin{array}{l}\text { Monte- } \\
\text { mor-o-No- } \\
\text { vo }\end{array}$ & 8 & $9^{\circ}$ & Ensino regular & 2 & $\begin{array}{l}\text { Geografia e } \\
\text { Artes Visuais }\end{array}$ \\
\hline \multirow{2}{*}{ Évora } & 4 & $9^{\circ}$ & Ensino regular & 2 & $\begin{array}{l}\text { Ensino de } \\
\text { Português e } \\
\text { Francês e Ar- } \\
\text { tes Plásticas }\end{array}$ \\
\hline & 6 & $10^{\circ}$ & $\begin{array}{l}\text { Clube com alu- } \\
\text { nos de várias } \\
\text { turmas }\end{array}$ & 4 & $\begin{array}{l}\text { Ciências } \\
\text { Socioeconó- } \\
\text { micas }\end{array}$ \\
\hline \multirow{5}{*}{$\begin{array}{l}\text { Vila Vi- } \\
\text { çosa }\end{array}$} & 9 & $9^{\circ}$ & Ensino regular & \multirow{5}{*}{1} & \multirow{5}{*}{$\begin{array}{l}\text { Ciências So- } \\
\text { ciais }\end{array}$} \\
\hline & 25 & $10^{\circ}$ & $\begin{array}{l}\text { Ciências e Tec- } \\
\text { nologias }\end{array}$ & & \\
\hline & 15 & $10^{\circ}$ & Artes & & \\
\hline & 29 & $10^{\circ}$ & $\begin{array}{l}\text { Línguas e Hu- } \\
\text { manidades }\end{array}$ & & \\
\hline & 19 & $10^{\circ}$ & $\begin{array}{l}\text { Ciências e Tec- } \\
\text { nologias }\end{array}$ & & \\
\hline \multirow{2}{*}{ Elvas } & 17 & $11^{\circ}$ & $\begin{array}{l}\text { Técnico de } \\
\text { Auxiliar de } \\
\text { Saúde }\end{array}$ & 2 & $\begin{array}{l}\text { Secretariado } \\
\text { e ciências } \\
\text { socioeconó- } \\
\text { micas }\end{array}$ \\
\hline & 13 & $9^{\circ}$ & $\begin{array}{l}\text { CEF de Hote- } \\
\text { laria e Serviço } \\
\text { de Andares }\end{array}$ & 2 & $\begin{array}{l}\text { Literatura } \\
\text { moderna e } \\
\text { turismo }\end{array}$ \\
\hline
\end{tabular}

participantes (município de origem, número de alunos que constituem a "empresa", ano e curso frequentado, número de professores participantes e respetiva área de formação).

Procurando fazer face a uma das principais limitações dos programas de treino de competências empreendedoras, a pouca importância dada à sua avaliação (Garavan \& O'Cinneide, 1994), e considerando que as boas práticas devem ser apresentadas à comunidade, assim como os seus resultados, (Jesus, Nave, Gonçalves, Caleça, \& Oliveira, 2011) ao longo da implementação deste projeto foi levado a cabo um processo de avaliação multifacetado incluindo pré e pós-teste, assim como grupo de controlo. Neste trabalho pretende-se conhecer a opinião de alunos e professores que participaram na implementação do Programa Empreender na Escola, procurando, em última instância, obter pistas para o desenvolvimento e implementação de outros programas de educação para o empreendedorismo e contribuir para o desenvolvimento da literatura existente sobre a temática.

\section{Metodologia}

\section{Participantes}

A amostra deste estudo foi recolhida de forma aleatória e é constituída por 51 participantes que se distribuem pelos 7 municípios, abrangendo todas as "empresas" criadas.

Os alunos inquiridos são essencialmente do sexo masculino $(61,3 \%)$ e apresentam idades entre os 14 e os 22 anos $(M=16,71, D P=2,22)$. Os jovens empreendedores frequentam o $3^{\circ}$ ciclo ou o ensino secundário, na sua maioria em cursos ligados à área das Ciências e Tecnologias $(\mathrm{N}=14)$. Em termos de tipo de ensino frequentado, a maior parte dos inquiridos frequenta cursos profissionais $(\mathrm{N}=11)$.

Por sua vez, os professores auscultados são na sua maioria do sexo feminino ( $80 \%$ ), com idades compreendidas entre 26 e 58 anos $(M=45,25$, $\mathrm{DP}=9,64)$. Embora apresentem áreas de formação 
diferentes, a maior parte está associado a áreas relacionadas com as Ciências e Tecnologias $(\mathrm{N}=8)$.

\section{Instrumentos}

Para a recolha de dados foi especialmente desenvolvido um instrumento constituído por três partes distintas. A primeira destinou-se à recolha das características sociodemográficas dos professores e alunos, nomeadamente sexo, idade, instituição de ensino e área de formação. Já a segunda foi dedicada à recolha da avaliação quantitativa dos participantes no Programa Empreender na Escola, tendo em conta os objetivos e conteúdos do Programa, a sua metodologia, o interesse de professores e alunos na sua implementação, as atividades desenvolvidas ao longo do ano letivo, a ligação entre a teoria apresentada no Programa e a prática empresarial e o progresso de alunos e professores ao longo da sua participação no Programa, avaliados numa escala de tipo Likert de 5 pontos, variando entre 1 (não concordo) e 5 (concordo muitíssimo). Por último, a terceira parte foi orientada para a recolha de opiniões dos participantes sobre a sua participação no Programa, nomeadamente os aspetos mais relevantes ou úteis, os aspetos que menos agradaram e as sugestões para o aperfeiçoamento do Programa.

\section{Procedimentos}

Os questionários foram aplicados coletivamente na Feira Temática de encerramento do Programa Empreender na Escola que se realizou em Évora e acolheu todas as "empresas" participantes e os professores envolvidos.

Para a análise dos dados recorreu-se ao programa estatístico de tratamento de dados IBM SPSS Statistics versão 19. Com o objetivo de caracterizar a amostra foram calculadas as frequências descritivas e determinadas as médias e desvios-padrão das variáveis sociodemográficas recolhidas. Já na análise das respostas obtidas, calculou-se a sua pontuação mínima, máxima, frequência, percentagem, média e desvio-padrão, assim como a análise de diferenças entre alunos e professores e calculadas as magnitudes dos efeitos obtidos. No caso das perguntas abertas recorreu-se ainda à técnica de análise de conteúdo.

\section{Resultados}

Nas tabelas 2, 3 e 4 são apresentadas as opiniões dos alunos e professores inquiridos sobre as características e particularidades da implementação do Programa Empreender na Escola. No que se refere aos aspetos gerais do Programa (tabela 2) foram avaliadas as seguintes dimensões: objetivos e conteúdos, metodologia e materiais adotados, desempenho dos sócios empresariais e avaliação dos professores. Os resultados obtidos ao nível dos objetivos e conteúdos do Programa evidenciam uma boa avaliação destas dimensões por parte de alunos e professores, sendo de destacar a existência de diferenças estatisticamente significativas, favorecendo os professores, ao nível da clareza dos objetivos do Programa $(\mathrm{F}(50)=1,2014, p=0,012$, IC 95\% $=[3,75,4,39])$, da seleção e da organização dos seus conteúdos programáticos $(\mathrm{F}(50)=6,787$, $p=0,012$, IC $95 \%=[4,10,4,50])$ e do interesse prático que tem para a formação dos alunos $(\mathrm{F}(50)$ $=5,880, p=0,019$, IC 95\% = [4,17, 4,71]). Estas diferenças são consideradas de magnitude intermédia no caso da seleção e da organização dos seus conteúdos programáticos $(\mathrm{d}=0,79)$ e interesse prático para a formação dos alunos $(\mathrm{d}=0,71)$, enquanto no caso da clareza dos objetivos do projeto é de pequena magnitude $(\mathrm{d}=0,32)$.

Ao nível da avaliação da metodologia e dos materiais adotados, ambos apresentam uma boa avaliação das dimensões consideradas. Importa, contudo, sublinhar que os professores apresentam avaliações mais elevadas do que os alunos, sendo estas diferenças estatisticamente significativas ao nível da utilidade da metodologia e materiais ado$\operatorname{tados}(\mathrm{F}(48)=16,091, p=0.000, \mathrm{IC} 95 \%=[3,73$, $4,17])$ e da organização/construção dos materiais 
Tabela 2

Avaliação de alunos e professores sobre os aspetos gerais do Programa Empreender na Escola

\begin{tabular}{|c|c|c|c|c|c|c|c|c|c|c|}
\hline & \multicolumn{3}{|c|}{ Alunos } & \multicolumn{3}{|c|}{ Professores } & \multirow[b]{2}{*}{$F$} & \multirow[b]{2}{*}{$p$} & \multirow[b]{2}{*}{$g l$} & \multirow[b]{2}{*}{$\mathrm{D}$} \\
\hline & $\mathrm{N}^{\mathrm{o}}$ & $\begin{array}{l}\text { Min. } \\
\text { Máx. }\end{array}$ & $\begin{array}{c}\mathrm{M} \\
\text { (DP) }\end{array}$ & $\mathrm{N}^{\mathrm{o}}$ & $\begin{array}{l}\text { Min. } \\
\text { Máx. }\end{array}$ & $\begin{array}{c}\mathrm{M} \\
\text { (DP) }\end{array}$ & & & & \\
\hline \multicolumn{11}{|c|}{ Objetivos e conteúdos do Programa } \\
\hline $\begin{array}{l}\text { Adequação dos conteúdos do Programa à reali- } \\
\text { dade empresarial }\end{array}$ & 31 & $\begin{array}{l}3 \\
5\end{array}$ & $\begin{array}{c}3,97 \\
(0,71)\end{array}$ & 20 & $\begin{array}{l}3 \\
5\end{array}$ & $\begin{array}{c}3,95 \\
(0,76)\end{array}$ & 0,007 & 0,933 & 50 & 0,03 \\
\hline $\begin{array}{l}\text { Adequação dos conteúdos do Programa à reali- } \\
\text { dade educativa }\end{array}$ & 31 & $\begin{array}{l}3 \\
5\end{array}$ & $\begin{array}{c}3,68 \\
(0,80)\end{array}$ & 20 & $\begin{array}{l}2 \\
5\end{array}$ & $\begin{array}{c}3,55 \\
(0,95)\end{array}$ & 0,271 & 0,605 & 50 & 0,15 \\
\hline Clareza dos objetivos do Programa & 31 & $\begin{array}{l}1 \\
5\end{array}$ & $\begin{array}{c}3,81 \\
(1,05)\end{array}$ & 20 & $\begin{array}{l}3 \\
5\end{array}$ & $\begin{array}{l}(4,1) \\
0,72\end{array}$ & 1,204 & 0,012 & 50 & 0,32 \\
\hline $\begin{array}{l}\text { Seleção e organização dos seus conteúdos } \\
\text { programáticos }\end{array}$ & 31 & $\begin{array}{l}2 \\
5\end{array}$ & $\begin{array}{c}3,71 \\
(0,94)\end{array}$ & 20 & $\begin{array}{l}4 \\
5\end{array}$ & $\begin{array}{l}(4,3) \\
0,47\end{array}$ & 6,787 & $0,012^{*}$ & 50 & 0,79 \\
\hline $\begin{array}{l}\text { Interesse prático da participação no Programa } \\
\text { para a formação dos alunos }\end{array}$ & 31 & $\begin{array}{l}3 \\
5\end{array}$ & $\begin{array}{c}3,94 \\
(0,81)\end{array}$ & 20 & $\begin{array}{l}3 \\
5\end{array}$ & $\begin{array}{c}4,45 \\
(0,61)\end{array}$ & 5,880 & $0,019^{*}$ & 50 & 0,71 \\
\hline \multicolumn{11}{|c|}{ Metodologia e materiais adotados } \\
\hline Utilidade dos materiais & 30 & $\begin{array}{l}2 \\
5\end{array}$ & $\begin{array}{c}3,62 \\
(0,78)\end{array}$ & 20 & $\begin{array}{l}3 \\
5\end{array}$ & $\begin{array}{l}4,45 \\
(0,61)\end{array}$ & 16,091 & $0,000^{*}$ & 48 & 1,19 \\
\hline Organização/construção dos materiais & 30 & $\begin{array}{l}3 \\
5\end{array}$ & $\begin{array}{c}3,77 \\
(0,82)\end{array}$ & 20 & $\begin{array}{l}3 \\
5\end{array}$ & $\begin{array}{c}4,5 \\
(0,61)\end{array}$ & 11,748 & $0,001^{*}$ & 48 & 0,94 \\
\hline $\begin{array}{l}\text { Avaliação da apresentação da metodologia do } \\
\text { Programa no início da sua implementação }\end{array}$ & 30 & $\begin{array}{l}2 \\
5\end{array}$ & $\begin{array}{c}3,63 \\
(0,96)\end{array}$ & 20 & $\begin{array}{l}3 \\
5\end{array}$ & $\begin{array}{c}4,00 \\
(0,86)\end{array}$ & 1,890 & 0,176 & 48 & 0,41 \\
\hline Diversidade da metodologia adotada & 30 & $\begin{array}{l}2 \\
5\end{array}$ & $\begin{array}{c}3,57 \\
(0,86)\end{array}$ & 20 & $\begin{array}{l}3 \\
5\end{array}$ & $\begin{array}{c}3,90 \\
(0,79)\end{array}$ & 1,930 & 0,171 & 48 & 0,40 \\
\hline $\begin{array}{l}\text { Aproveitamento das potencialidades dos alu- } \\
\text { nos ao longo da implementação }\end{array}$ & 30 & $\begin{array}{l}3 \\
5\end{array}$ & $\begin{array}{c}3,83 \\
(0,83)\end{array}$ & 20 & $\begin{array}{l}3 \\
5\end{array}$ & $\begin{array}{c}3,70 \\
(0,66)\end{array}$ & 0,006 & 0,939 & 48 & 0,17 \\
\hline $\begin{array}{l}\text { Aproveitamento das potencialidades dos pro- } \\
\text { fessores ao longo da implementação }\end{array}$ & 30 & & $\begin{array}{c}3,77 \\
(0,77)\end{array}$ & 20 & $\begin{array}{l}3 \\
5\end{array}$ & $\begin{array}{l}3,75 \\
(0,72)\end{array}$ & 0,361 & 0,551 & 48 & 0,03 \\
\hline \multicolumn{11}{|c|}{ Desempenho dos sócios } \\
\hline Interesso dos alunos & 30 & $\begin{array}{l}1 \\
5\end{array}$ & $\begin{array}{c}3,57 \\
(1,19)\end{array}$ & 20 & $\begin{array}{l}1 \\
5\end{array}$ & $\begin{array}{c}3,05 \\
(1,17)\end{array}$ & 2,391 & 0,129 & 49 & 0,44 \\
\hline $\begin{array}{l}\text { Contribuição para o aprofundamento dos te- } \\
\text { mas abordados }\end{array}$ & 30 & $\begin{array}{l}2 \\
5\end{array}$ & $\begin{array}{c}3,7 \\
(0,95) \\
\end{array}$ & 20 & $\begin{array}{l}1 \\
5\end{array}$ & $\begin{array}{c}2,95 \\
(1,00)\end{array}$ & 7,160 & $0,010^{*}$ & 49 & 0,77 \\
\hline $\begin{array}{l}\text { Contribuição para o alcance dos objetivos do } \\
\text { Programa }\end{array}$ & 30 & $\begin{array}{l}2 \\
5\end{array}$ & $\begin{array}{c}3,73 \\
(1,02)\end{array}$ & 20 & $\begin{array}{l}1 \\
5\end{array}$ & $\begin{array}{c}2,8 \\
(1,06) \\
\end{array}$ & 9,826 & $0,003 *$ & 49 & 0,89 \\
\hline \multicolumn{11}{|c|}{ Avaliação dos professores } \\
\hline Domínio dos conteúdos do Programa & 30 & $\begin{array}{l}2 \\
5\end{array}$ & $\begin{array}{c}3,9 \\
(1,00)\end{array}$ & 20 & $\begin{array}{l}1 \\
5\end{array}$ & $\begin{array}{c}3,65 \\
(1,18)\end{array}$ & 0,652 & 0,424 & 49 & 0,22 \\
\hline $\begin{array}{l}\text { Domínio da metodologia adotada pelo Pro- } \\
\text { grama }\end{array}$ & 30 & $\begin{array}{l}2 \\
5\end{array}$ & $\begin{array}{c}3,97 \\
(1,00)\end{array}$ & 20 & $\begin{array}{l}1 \\
5\end{array}$ & $\begin{array}{c}3,5 \\
(1,15) \\
\end{array}$ & 2,324 & 0,134 & 49 & 0,44 \\
\hline Motivação para a implementação do Programa & 30 & $\begin{array}{l}1 \\
5\end{array}$ & $\begin{array}{c}3,9 \\
(1,00)\end{array}$ & 20 & $\begin{array}{l}1 \\
5\end{array}$ & $\begin{array}{c}3,75 \\
(1,16)\end{array}$ & 0,238 & 0,628 & 49 & 0,13 \\
\hline $\begin{array}{l}\text { Manifestação de disponibilidade para clarificar } \\
\text { dúvidas e apoiar }\end{array}$ & 30 & $\begin{array}{l}3 \\
5\end{array}$ & $\begin{array}{c}4,13 \\
(0,86)\end{array}$ & 20 & $\begin{array}{l}1 \\
5\end{array}$ & $\begin{array}{c}3,95 \\
(1,19)\end{array}$ & 0,400 & 0,530 & 49 & 0,17 \\
\hline
\end{tabular}

* $\mathrm{p}<, 05$ 
utilizados $(\mathrm{F}(48)=11,748, p=0,001$, IC 95\%= $[4,22,4,75])$, ambas de grande magnitude.

Na avaliação do desempenho dos sócios empresariais e dos professores ao longo da implementação do Programa, os alunos pontuaram mais alto do que os professores em todas as dimensões avaliadas. No que concerne ao desempenho dos alunos, verifica-se também a existência de diferenças significativas ao nível da avaliação da sua contribuição para o aprofundamento dos temas abordados $(\mathrm{F}(49)=7,160$, $p=0.010$, IC $95 \%=[3,35,4,03])$ e do alcance dos objetivos do Programa $(\mathrm{F}(49)=9,826, p=0,003$, IC $95 \%=[3,29,4,00])$, sendo a primeira de magnitude intermédia $(\mathrm{d}=0,77)$ e a segunda de grande magnitude $(\mathrm{d}=0,89)$. Além disso, é de notar que estas dimensões são avaliadas de forma negativa pelos professores. Relativamente à avaliação do desempenho dos professores, importa referir que não se observaram diferenças estatisticamente significativas entre alunos e professores, sendo que os alunos pontuam mais alto do que os professores em todas as dimensões.

Procurando saber a opinião dos participantes sobre o desempenho das "empresas, pedimos ainda que avaliassem a realização das principais tarefas. Os resultados desta avaliação encontram-se apresentados na tabela 3. Através da análise desta tabela, é possível observar que as tarefas mais pontuadas pelos alunos são a elaboração do catálogo de produtos $(\mathrm{M}=3,97, \mathrm{DP}=0,912)$ e a comercialização dos produtos na Feira Temática $(\mathrm{M}=3,97, \mathrm{DP}=0,912)$, pontuando mais baixo a obtenção do capital $\operatorname{social}(\mathrm{M}=3,29, \mathrm{DP}=1,131)$. Os professores, por sua vez, apresentam pontuações mais elevadas na abertura da conta bancária $(\mathrm{M}=$ 4,60, DP = 0,821), na elaboração do catálogo de produtos $(\mathrm{M}=4,55, \mathrm{DP}=0,605)$ e na "exportação" dos produtos para a "empresa" parceira $(\mathrm{M}=4,55$, $\mathrm{DP}=0,686$ ), enquanto a comercialização dos produtos "importados" da "empresa" parceira através do Facebook foi a que obteve uma pontuação mais baixa $(\mathrm{M}=2,70, \mathrm{DP}=1,490)$.
Por outro lado, observa-se ainda a existência de diferenças significativas na avaliação de algumas destas tarefas-chave. De uma forma geral, os alunos pontuaram significativamente mais alto o desempenho das miniempresas na comercialização dos produtos “importados" através do Facebook $(\mathrm{F}(49)$ $=5,793, p=0,02, \mathrm{~d}=0,65, \operatorname{IC} 95 \%=[3,21,4,00])$ e em eventos locais $(\mathrm{F}(49)=6,737, p=0,012$, $\mathrm{d}$ $=0,71$, IC $95 \%=[3,59,4,23])$. Já a avaliação dos professores foi estatisticamente mais elevada na "exportação" dos produtos para a "empresa" parceira $(\mathrm{F}(49)=7,403, p=0,009, \mathrm{~d}=0,80, \mathrm{IC} 95 \%$ $=[4,22,4,82])$ e na "importação" dos produtos da "empresa" parceira $(\mathrm{F}(49)=6,646, p=0,013, \mathrm{~d}=$ $0,76$, IC $95 \%=[4,14,4,80])$, assim como na abertura da conta bancária $(\mathrm{F}(49)=6,468, p=0,014, \mathrm{~d}$ $=0,74$, IC $95 \%=[4,22,4,92])$, na elaboração do catálogo de produtos $(\mathrm{F}(49)=6,327, p=0,015, \mathrm{~d}=$ $0,75$, IC $95 \%=[4,29,4,79])$ e na comercialização dos produtos "importados" na própria escola $(\mathrm{F}(49)$ $=4,530, p=0,038, \mathrm{~d}=0,63, \mathrm{IC} 95 \%=[3,62,4,22])$. Ressalva-se que a maioria dos efeitos foi superior a 0,60 , indicando uma diferença intermédia entre os grupos, com exceção da tarefa de "exportação" dos produtos para a "empresa" parceira, que apresenta uma diferença grande.

Procurámos igualmente recolher a opinião dos participantes sobre os aspetos mais relevantes ou úteis da sua participação no Programa, assim como as particularidades que menos lhes agradaram e as sugestões que têm para melhoria de edições futuras deste projeto (tabela 4). Na análise dos resultados obtidos recorremos à técnica de análise de conteúdo (Bardin, 1995), realizada em quatro fases. De forma geral, numa primeira fase procedeu-se à organização das respostas obtidas em cada uma das perguntas abertas colocadas aos participantes. Posteriormente procedeu-se à codificação das respostas obtidas. Nesta fase foram analisadas detalhadamente todas as respostas obtidas organizadas de acordo com a ideia expressa. Cada participante poderia dar mais do que uma resposta, pelo que todas as respostas foram divididas em unidades 
Tabela 3

Avaliação (média e desvio-padrão) das principais tarefas do Programa Empreender na Escola

\begin{tabular}{|c|c|c|c|c|c|c|}
\hline & \multicolumn{3}{|c|}{ Alunos } & \multicolumn{3}{|c|}{ Professores } \\
\hline & Min. & Máx. & $\begin{array}{c}\mathrm{M} \\
(\mathrm{DP})\end{array}$ & Min. & Máx. & $\begin{array}{c}\mathrm{M} \\
(\mathrm{DP})\end{array}$ \\
\hline $\begin{array}{l}\text { As "empresas" mantiveram relações próximas com a "empresa" } \\
\text { parceira }\end{array}$ & 1 & 5 & $\begin{array}{c}3,45 \\
(1,15)\end{array}$ & 2 & 5 & $\begin{array}{l}3,30 \\
(0,92)\end{array}$ \\
\hline $\begin{array}{l}\text { Os professores responsáveis das parcerias mantiveram relações } \\
\text { próximas }\end{array}$ & 2 & 5 & $\begin{array}{c}3,42 \\
(0,92)\end{array}$ & 2 & 5 & $\begin{array}{l}3,20 \\
(0,95)\end{array}$ \\
\hline $\begin{array}{l}\text { As "empresas" criaram e geriram a sua página de Facebook de for- } \\
\text { ma adequada e frequente }\end{array}$ & 2 & 5 & $\begin{array}{c}3,77 \\
(0,99)\end{array}$ & 2 & 5 & $\begin{array}{l}3,70 \\
(0,92)\end{array}$ \\
\hline $\begin{array}{l}\text { As "empresas" obtiveram de forma rápida e eficaz o seu capital } \\
\text { social }\end{array}$ & 1 & 5 & $\begin{array}{c}3,29 \\
(1,13)\end{array}$ & 1 & 5 & $\begin{array}{l}3,30 \\
(1,13)\end{array}$ \\
\hline $\begin{array}{l}\text { As "empresas" elaboraram uma imagem corporativa concordante } \\
\text { com o nome que escolheram }\end{array}$ & 2 & 5 & $\begin{array}{c}3,84 \\
(0,93)\end{array}$ & 3 & 5 & $\begin{array}{c}4,30 \\
(0,73)\end{array}$ \\
\hline $\begin{array}{l}\text { Os alunos, depois de divididos por unidades funcionais, mantive- } \\
\text { ram as suas responsabilidades até ao fim do Programa }\end{array}$ & 1 & 5 & $\begin{array}{c}3,23 \\
(1,23)\end{array}$ & 2 & 5 & $\begin{array}{c}3,20 \\
(1,01)\end{array}$ \\
\hline $\begin{array}{l}\text { As "empresas" identificaram produtos tradicionais do concelho e } \\
\text { identificaram fornecedores }\end{array}$ & 2 & 5 & $\begin{array}{c}3,80 \\
(1,03)\end{array}$ & 1 & 5 & $\begin{array}{c}3,80 \\
(1,11)\end{array}$ \\
\hline $\begin{array}{l}\text { As "empresas" elaboraram um catálogo de produtos para apresen- } \\
\text { tarem os produtos que escolheram vender }\end{array}$ & 2 & 5 & $\begin{array}{c}3,97 \\
(0,91)\end{array}$ & 3 & 5 & $\begin{array}{l}4,55 \\
(0,61)\end{array}$ \\
\hline As "empresas" abriram uma conta numa instituição bancária & 3 & 5 & $\begin{array}{c}3,94 \\
(0,96)\end{array}$ & 2 & 5 & $\begin{array}{c}4,60 \\
(0,82)\end{array}$ \\
\hline $\begin{array}{l}\text { As "empresas" "exportaram" os seus produtos para a "empresa" } \\
\text { parceira }\end{array}$ & 2 & 5 & $\begin{array}{c}3,90 \\
(0,91)\end{array}$ & 3 & 5 & $\begin{array}{l}4,55 \\
(0,69)\end{array}$ \\
\hline $\begin{array}{l}\text { As “empresas" "importaram" os seus produtos da "empresa" par- } \\
\text { ceira }\end{array}$ & 2 & 5 & $\begin{array}{c}3,84 \\
(0,97)\end{array}$ & 3 & 5 & $\begin{array}{l}4,50 \\
(0,76)\end{array}$ \\
\hline $\begin{array}{l}\text { As “empresas" comercializaram os produtos "importados" através } \\
\text { do Facebook }\end{array}$ & 1 & 5 & $\begin{array}{c}3,58 \\
(1,12)\end{array}$ & 1 & 5 & $\begin{array}{l}2,70 \\
(1,49)\end{array}$ \\
\hline $\begin{array}{l}\text { As “empresas" comercializaram os produtos "importados" na pró- } \\
\text { pria escola }\end{array}$ & 1 & 5 & $\begin{array}{c}3,68 \\
(1,14)\end{array}$ & 3 & 5 & $\begin{array}{c}4,30 \\
(0,80)\end{array}$ \\
\hline $\begin{array}{l}\text { As "empresas" comercializaram os produtos "importados" em } \\
\text { eventos locais }\end{array}$ & 2 & 5 & $\begin{array}{c}3,84 \\
(0,93)\end{array}$ & 1 & 5 & $\begin{array}{c}3,00 \\
(1,38)\end{array}$ \\
\hline $\begin{array}{l}\text { As "empresas" comercializaram os produtos "importados na Feira } \\
\text { Temática }\end{array}$ & 2 & 5 & $\begin{array}{c}3,97 \\
(0,91)\end{array}$ & 2 & 5 & $\begin{array}{c}4,30 \\
(0,92)\end{array}$ \\
\hline
\end{tabular}

de registo De seguida as unidades de registo foram organizadas em categorias independentes formadas com base nos dados obtidos, sendo cada uma introduzida apenas numa categoria. Por último, procedeu-se ao tratamento informático dos resultados obtidos, analisando frequências de resposta e percentagens, tendo sempre em conta o grupo de participantes, ou seja, alunos ou professores.

Para a análise dos aspetos mais relevantes foram criadas seis categorias distintas (tabela 4), nomeadamente convívio com outras pessoas; aquisição de conhecimentos e desenvolvimento de competências; realismo do Programa e associação dos seus 
Tabela 4

Aspetos mais e menos positivos da participação no Programa Empreender na Escola e sugestões de melhoria para edições futuras

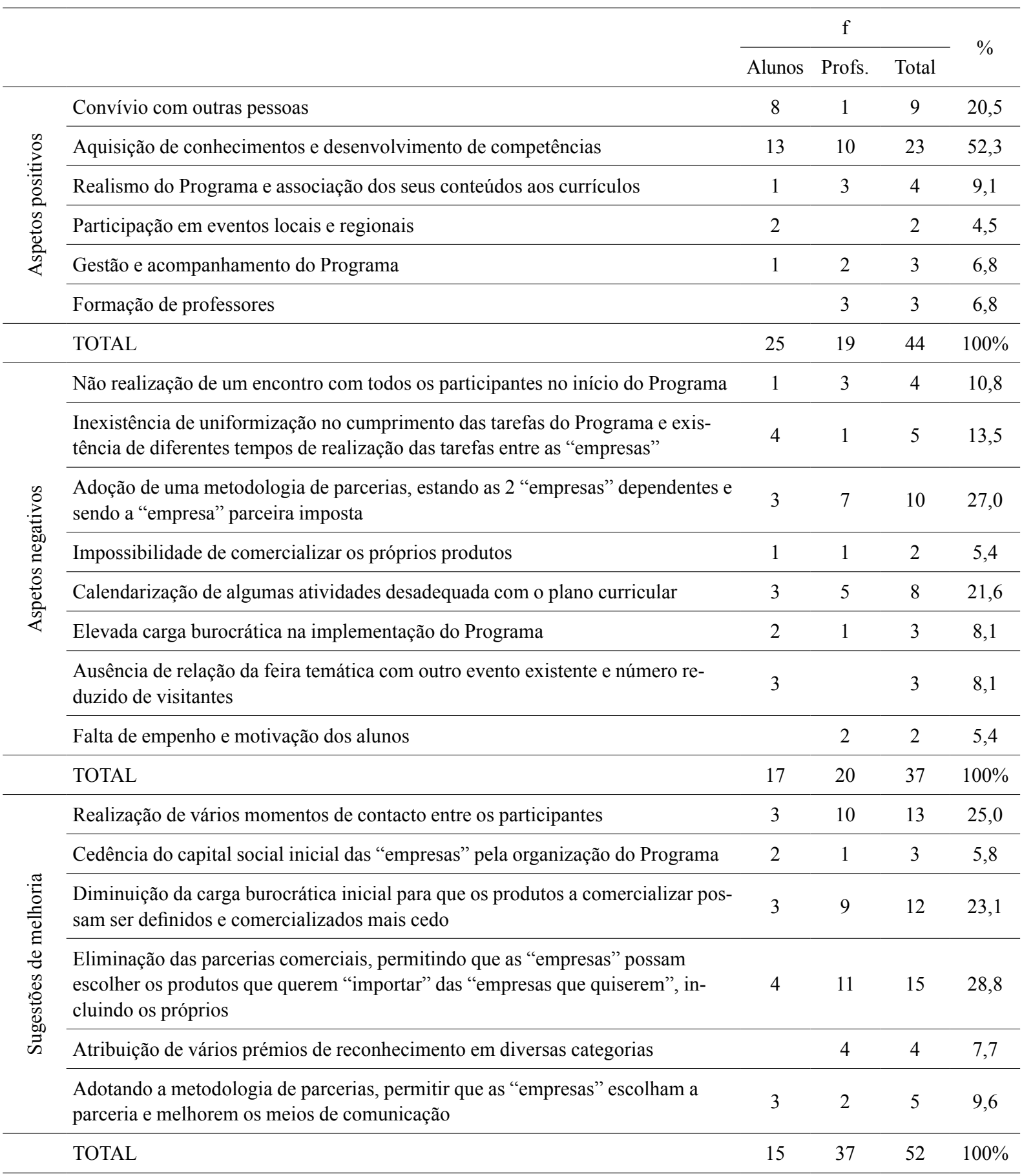

conteúdos aos currículos académicos; participação em eventos locais e regionais; gestão e acompanhamento do Programa; e formação de professores. Os resultados demonstram a importância da aquisição de conhecimentos sobre a temática do empreendedorismo e sobre a criação/gestão de empresas 
e o desenvolvimento de competências pessoais, referidos por 23 dos inquiridos (52,3\%).

Relativamente às particularidades que menos agradaram aos participantes (tabela 4), a maior parte dos inquiridos referiu a adoção de uma metodologia de parcerias $(27 \%, \mathrm{~N}=10)$, que fazia com que as duas "empresas" parceiras estivessem interdependentes, sendo de referir que as parcerias comerciais foram estabelecidas pela organização do Programa no início do ano letivo. Por outro lado, alguns alunos e professores referem ainda uma desadequação da calendarização de algumas atividades com o plano curricular do curso/ano frequentado $(21,6 \%, \mathrm{~N}=8)$.

A lista das sugestões apresentadas pelos participantes foi muito grande, pelo que optámos por contabilizar as que foram referidas mais do que duas vezes (tabela 4). De qualquer modo, e tendo em conta os aspetos referidos como menos satisfatórios, 15 dos participantes $(23,1 \%)$ sugerem uma alteração à conceção da metodologia de parceria, propondo que esta seja eliminada e as "empresas" possam "importar" e vender os produtos de qualquer uma das "empresas" participantes, incluindo a possibilidade de comercializarem os próprios.

\section{Discussão}

A promoção do empreendedorismo junto dos estudantes e a implementação de programas de educação para o empreendedorismo nas escolas são iniciativas cada vez mais frequentes no nosso país (Teixeira, 2012). Embora estas adotem diferentes metodologias, apresentam objetivos semelhantes, ou seja, o desenvolvimento de competências empresariais e empreendedoras e a aquisição de conhecimentos sobre o mundo empresarial e/ou sobre a transição da escola para o mundo do trabalho (Garavan \& O'Cinneide, 1994).

Tendo por base estes pressupostos e recorrendo a uma abordagem por competências que coloca os alunos em primeiro lugar, enquanto o professor desempenha o papel de orientador, foi desenhado o Programa Empreender na Escola (Imaginário et al., 2014). Este programa foi implementado em 12 escolas portuguesas de 7 municípios da região do Alentejo, durante o ano letivo de 2012/2013, oferecendo aos participantes a possibilidade de constituírem uma miniempresa de 'importação-exportação' que funcionava em parceria com outra "empresa". Os alunos envolvidos, sócios empresariais, tinham que gerir a sua "empresa" procurando obter o máximo de lucro possível e tinham a possibilidade de ser apoiadas por uma empresa mentora (Imaginário et al., 2014).

Neste trabalho pretendia-se conhecer a opinião de alguns dos seus intervenientes com o objetivo de refletir criticamente sobre o mesmo, uma vez que as boas práticas devem ser avaliadas e os seus resultados apresentados à comunidade científica (Jesus et al., 2011). Desta forma, considerou-se pertinente atender a opinião dos participantes, alunos e professores, sobre os objetivos e conteúdos do Programa Empreender na Escola, a sua metodologia, o interesse de professores e alunos na sua implementação, as atividades desenvolvidas ao longo do ano letivo, a ligação entre a teoria do programa e a prática empresarial e o progresso de alunos e professores ao longo da sua participação no mesmo, assim como os aspetos que consideraram como mais relevantes ou úteis, os que menos agradaram e as suas sugestões de melhoria.

\section{Preparação do Programa Empreender na Escola}

No que se refere à adequação do Programa Empreender na Escola à realidade empresarial e ao ambiente educativo, alunos e professores, consideram que o Programa se encontra bem adaptado. Sobre a questão empresarial importa referir que este projeto foi desenhado tendo em conta os passos que uma empresa tem que ultrapassar para se poder constituir legalmente (Imaginário et al., 2014), desde a escolha do seu nome e imagem corporativa, ao preenchimento do pacto social, à 
seleção e recrutamento de colaboradores, à escolha dos produtos a comercializar e à definição da sua estratégia de marketing, ao estabelecimento de parcerias comerciais, à elaboração de documentação empresarial e à venda propriamente dita. $\mathrm{O}$ programa permite assim que os participantes contactem com as diferentes atividades realizadas, por parte de uma empresa, desde a sua constituição até à sua imposição no mercado. Todavia, é de notar que a carga burocrática que este processo acarreta, especialmente nas tarefas do bloco da constituição da empresa, leva os participantes a considerar que a mesma é excessiva e morosa. Embora os professores compartilhem esta perceção com os alunos, consideram que os conteúdos do Programa foram bem selecionados e organizados e que têm interesse prático para a formação dos alunos.

Este resultado reflete a opinião que os empresários têm, em grande parte dos casos, sobre o processo de criação da sua própria empresa. Assim sendo, embora este seja um indicador negativo da implementação do Programa Empreender na Escola, pode-se concluir que denota uma reprodução fiel da experiência de criação de empresas vivida pelos empreendedores no nosso país.

Sobre a adequação do Programa ao contexto escolar importa fazer a distinção entre os conteúdos e a calendarização das atividades. Relativamente aos conteúdos, ou seja, às atividades e tarefas propriamente ditas, note-se que no momento da sua conceção foram tidos em conta os diferentes conteúdos curriculares das disciplinas lecionadas no $9^{\circ}$ ano e no ensino secundário para que existisse uma ligação direta entre ambos (Imaginário et al., 2014). Por exemplo, a sessão 2 contemplada no Manual do Aluno (Cristo et al., 2012b) tem como objetivo a caracterização dos concelhos da parceria de "empresas" pelo que se recorre a diferentes indicadores de população e diversidade cultural, enquadra-se na disciplina de Geografia do $9^{\circ}$ ano, pois as competências a adquirir nesta disciplina prendem-se com três domínios: localização, conhecimento dos lugares e regiões e dinamismo das inter-relações entre os espaços (Tema: População e Povoamento). Já ao nível do Curso Profissional de Informática de Gestão, $10^{\circ}$ ano, esta tarefa insere-se na disciplina de Integração, que possui um currículo transversal remetendo para uma multiplicidade de conteúdos e conhecimentos que visam o desenvolvimento de competências de socialização laboral, na qual as tecnologias, o trabalho em equipa, a decisão participada e o empreendedorismo individual assumem importância decisiva (Área 1: A Sociedade, Unidade Temática 4: A Região, O Espaço Vivido, Tema 1: Identidade Regional). $\mathrm{Na}$ verdade, esta particularidade é até identificada como um dos aspetos que mais agradaram aos participantes (9,1\% das respostas), podendo-se afirmar que esta adaptação foi bem conseguida e se revelou como vantajosa para a implementação do programa na sua multiplicidade de contextos escolares.

Sobre a adequação da calendarização das tarefas, veja-se que, tendo em conta a diversidade de contextos educativos das miniempresas e das escolas participantes, nem todas as atividades foram desenvolvidas ao mesmo tempo ou até pela mesma ordem. Este foi até um dos aspetos que menos agradou aos participantes, tendo $13,5 \%$ referido "inexistência de uniformização no cumprimento das tarefas do Programa e existência de diferentes tempos de realização das tarefas" e 21,6\% a "calendarização de algumas atividades desadequada com o plano curricular". Relativamente à calendarização especificamente, importa focar duas das principais tarefas do Programa: a feira temática de encerramento e o início da comercialização dos produtos. A feira realizou-se após o encerramento do ano letivo dos alunos do $9^{\circ}$ ano. Contudo, os alunos dos cursos profissionais já tinham terminado o seu período letivo e estavam em altura de estágio, enquanto os estudantes do $9^{\circ}$ ano estavam a dar início ao seu período de exames nacionais. A comercialização dos produtos "importados" no $3^{\circ}$ período foi condicionada pelas sessões de preparação para os exames nacionais e também pela entrada de alguns alunos para os estágios profis- 
sionais. Aliás, $23,1 \%$ das sugestões apresentadas pelos participantes remetem para a necessidade de diminuir a carga burocrática inicial para que a comercialização dos produtos possa começar mais cedo, fazendo assim face a esta limitação em edições futuras.

Os participantes, principalmente os professores, reconhecem a utilidade dos materiais desenvolvidos para a implementação do Programa, nomeadamente os manuais e a plataforma de formulários, assim como a sua organização/construção. No entanto, referem que seria benéfico que cada aluno, ou pelo menos cada unidade funcional, pudesse ter acesso a um exemplar do Manual do Aluno para poder acompanhar mais facilmente as tarefas a ser desenvolvidas. De facto apenas foi entregue um exemplar a cada miniempresa, pelo que na realização de outras edições é importante ter em conta esta sugestão. Por outro lado, consideram igualmente vantajoso que no início de um programa de intervenção deste género, fosse feita uma sessão de apresentação para os alunos e professores participantes, com o objetivo de expor a sua metodologia e os materiais de suporte, ao mesmo tempo que permite esclarecer eventuais dúvidas.

\section{Implementação do Programa Empreender na Escola}

Na apreciação global do desempenho dos participantes, é de destacar que os alunos apresentam avaliações mais elevadas da sua própria atividade e do desempenho dos professores, sendo de notar a existência de diferenças significativas ao nível da sua contribuição para o aprofundamento dos temas abordados e para o alcance dos objetivos do Programa. Este resultado poderá demonstrar que as expetativas dos professores sobre o seu próprio desempenho e sobre as tarefas desenvolvidas pelos seus alunos não foram alcançadas, ou, em contrapartida poderá indicar algum desconhecimento, por parte dos alunos, sobre os objetivos e a metodologia do Programa, reforçando assim a necessidade de realização de uma sessão de apresentação inicial em edições futuras.

Esta diferença de perspetivas reflete-se também na avaliação que alunos e professores fazem das principais tarefas realizadas ao longo da implementação do Programa, sendo a elaboração do catálogo de produtos a "exportar" a atividade mais pontuada por ambos. Esta tarefa é, indubitavelmente, uma das mais relevantes, pois permite que as "empresas" se apresentem à comunidade local e divulguem os produtos que oferecem, bem como demonstrem os contactos que estabeleceram com o tecido empresarial local.

Quanto às tarefas que obtiveram uma pontuação mais baixa, os alunos destacam a obtenção do capital social, enquanto os professores referem a comercialização dos produtos "importados" da "empresa" parceira através da página do Facebook. A obtenção do capital social foi, na realidade, a tarefa que gerou mais controvérsia entre os alunos. O objetivo desta atividade era que recolhessem o montante necessário para darem início à atividade da sua empresa, entre 100 e 150 euros. Cabia aos alunos decidir a forma como o recolhiam (capital próprio, empréstimo da escola, empréstimo dos professores, apoio da empresa mentora) e o valor que angariavam. De forma geral, os alunos não queriam investir o seu próprio dinheiro e algumas miniempresas recorreram a outras estratégias que lhes permitisse juntar o montante pretendido, nomeadamente a confeção e comercialização de bolos, velas, sabonetes e ervas aromáticas, ou a obtenção de patrocínios.

Esta é, de facto, uma das atividades estruturantes do Programa Empreender na Escola, pois a utilização de dinheiro real nas transações comerciais contribuía para o realismo do programa, pelo que este resultado poderia refletir um insucesso no seu desempenho. Porém, importa sublinhar que com este projeto se pretendia fomentar o desenvolvimento de competências empreendedoras, nomeadamente a criatividade e a resolução de problemas. À luz deste pressuposto, este indicador reflete que 
o programa foi bem-sucedido no fomento destas competências, pois os alunos, ao não pretenderem utilizar o seu próprio dinheiro, optaram por encontrar outras estratégias que lhes permitisse obter o capital social inicial.

Por outro lado, a comercialização dos produtos no Facebook foi a tarefa que obteve a avaliação mais baixa por parte dos professores, verificando-se ainda a existência de uma diferença significativa na avaliação da mesma, favorecendo os alunos. Ao longo da implementação do projeto observou-se que todas as "empresas" colocaram os produtos que vendiam na sua página de Facebook, mas este meio não se mostrou viável para a comercialização dos produtos, contrariamente ao que foi conceptualizado, pois não existiram nenhumas transações comerciais efetuadas. O Facebook serviu apenas para que as "empresas" mostrassem o que tinham para oferecer, tendo a maior parte das vendas sido realizadas em feiras organizadas na escola ou em eventos locais existentes, tarefas estas bem pontuadas por parte dos participantes. Este indicador foi, de certa forma inesperado, uma vez que atualmente é dada muita importância a esta plataforma social, principalmente nas camadas mais jovens da população, pelo que se esperava que a divulgação do catálogo de produtos no Facebook levasse à comercialização dos produtos disponíveis. Todavia, o principal objetivo desta rede social é o estabelecimento de relações interpessoais, e não a comercialização de produtos, pelo que na implementação de projetos que pretendam utilizar a internet para comercialização de produtos recomenda-se a utilização de uma plataforma especialmente destinada ao e-commerce.

Após análise dos aspetos mais e menos positivos da sua participação no Programa Empreender na Escola e das sugestões apresentadas pelos inquiridos deve chamar-se a atenção para algumas particularidades. O estabelecimento de relações interpessoais e o convívio entre alunos, professores e escolas é apontado como uma das características mais relevantes da participação neste projeto. Em- bora o contacto físico entre a maior parte dos participantes só se tenha realizado na Feira Temática, as parcerias puderam comunicar diretamente através de um grupo restrito que foi especificamente criado na página do Facebook do Programa e alguns professores tiveram a possibilidade de se conhecer pessoalmente através da ação de formação realizada ou da troca direta de produtos. Neste sentido, e tendo em conta as sugestões feitas por parte dos participantes, seria importante aumentar e melhorar esta particularidade, por exemplo através da criação de um momento de contacto inicial entre todos os participantes. Além disso, não é possível deixar de sublinhar que a participação neste projeto levou a uma óbvia aproximação entre alunos e professores de cada uma das miniempresas, pelo que este resultado pode ainda espelhar o agrado dos participantes com esta relação. Indicador semelhante foi obtido na avaliação do projeto "A Empresa", onde Chaves e Parente (2011) concluíram que o professor assumiu um papel ativo junto dos alunos, encorajando-os a refletir sobre as tarefas a realizar, motivando-os para a gestão da sua "empresa" e auxiliando-os na realização das suas tarefas.

A metodologia adotada deve ser igualmente alvo de reflexão, principalmente pelo facto de algumas das suas características terem sido identificadas como aspetos menos positivos. Como referido, o programa pressupunha a criação e gestão de uma “empresa" de "importação-exportação", sendo que as "empresas" iriam trabalhar em parcerias constituídas com base em critérios de distância geográfica e heterogeneidade de características sociodemográficas. Assim sendo, as duas miniempresas constituintes de uma parceria estavam dependentes ao nível da "importação" e "exportação" dos produtos que seriam posteriormente comercializados para o consumidor final. Tendo em conta as particularidades do curso frequentado, os calendários escolares e as próprias características dos sócios empresariais, as "empresas" acabavam por apresentar diferentes tempos de execução das tarefas, o que limitava a atividade da "empresa" parceira, 
caso uma estivesse mais adiantada. Atendendo a esta limitação, os próprios participantes sugerem que em futuras edições não se recorra a uma metodologia de parcerias comerciais, mas antes permitir que cada miniempresa possa escolher os produtos que pretende "importar" de qualquer uma das "empresas" participantes. Por alternativa, sugerem que, caso se pretenda manter a metodologia de parcerias, deve ser permitido a cada "empresa" eleger a parceira.

A constituição de parcerias entre duas "empresas" permite a aproximação e o estabelecimento de relações entre alunos e professores, levando-os a contactar com diferentes realidades, culturas e pessoas. A desvantagem desta metodologia é que, caso as "empresas" não tenham o mesmo ritmo de trabalho, a mais avançada ficará prejudicada e não conseguirá avançar na sua atividade. Atendendo a esta questão e à sua implicação na comercialização dos produtos "importados", bem como à importância do estabelecimento de relações interpessoais e do contacto com diferentes realidades, seria desejável que as atividades do programa fossem antecipadas para que a troca de produtos entre as "empresas" pudessem ser iniciadas no final do $1^{\circ}$ período, aumentando desta forma o tempo de comercialização dos produtos e reduzindo a carga burocrática inicial.

\section{O Programa Empreender na Escola em resumo}

Em suma, verifica-se que as principais mais-valias atribuídas ao Programa Empreender na Escola se prendem com a adequação dos seus conteúdos à realidade empresarial e aos currículos académicos do público estudantil a que se destina, assim como aos manuais utilizados e à plataforma dos formulários disponível para auxiliar a gestão da miniempresa criada. Por outro lado, é de sublinhar a importância atribuída pelos participantes às relações interpessoais estabelecidas, fomentada pela adoção de uma metodologia de parcerias comerciais, pelo envolvimento ativo dos professores na gestão das suas miniempresas e pela utilização privilegiada do Facebook como meio de comunicação entre todos os participantes. As fraquezas deste programa de educação para o empreendedorismo estão essencialmente associadas à elevada carga burocrática que apresenta, assim como à interdependência que as "empresas" parceiras tinham. Além disso, é de notar que o facto das miniempresas frequentarem diferentes tipos de ensino acabou por originar uma heterogeneidade no desenrolar do projeto ao nível das características das "empresas" e do seu calendário escolar, o que se refletiu nas tarefas realizadas.

Não podemos deixar ainda de salientar que as constantes alterações feitas ao plano curricular dos alunos, assim como a eliminação das disciplinas mais práticas do currículo escolar se constituíram como fortes ameaças ao desenvolvimento e implementação deste programa de educação para o empreendedorismo. Contudo, a temática do empreendedorismo e das competências empreendedoras tem vindo a ganhar importância no meio social e no meio académico, pelo que vivemos num período privilegiado para a implementação de programas deste género.

\section{Conclusões}

A temática do empreendedorismo e da educação para o empreendedorismo tem vindo a ganhar força nas últimas décadas, não só através do ensino académico e do fomento da criação da própria empresa, mas também da implementação de programas de treino em escolas desde o primeiro ciclo até ao ensino superior (por exemplo, Chaves \& Parente, 2011; Comissão Europeia, 2002; Direção-Geral de Inovação e Desenvolvimento Curricular do Ministério da Educação, 2009; Parkurbis, 2007; Rocha et al., 2012; Teixeira, 2012).

Antes da implementação de um programa de educação para o empreendedorismo, independentemente da metodologia adotada, consideramos pertinente realizar um exercício de adaptação do 
mesmo ao sistema de educação em vigor. $\mathrm{O}$ contexto educativo sofre constantes mudanças ao longo dos anos letivos e nos últimos anos têm sido eliminadas do currículo educativo as disciplinas que apresentavam uma componente mais prática e onde se enquadravam facilmente este tipo de projeto. Os resultados obtidos nesta investigação demonstram que o programa a implementar deve estar adaptado à realidade escolar de modo a permitir o envolvimento ativo de alunos e professores, assim como o alcance dos objetivos educativos propostos. Além disso, atendendo à multiplicidade de tipos de ensino e cursos existentes ao nível do ensino básico e secundário, consideramos que o programa desenhado deve ser suficientemente amplo para se conseguir adaptar de forma eficaz a qualquer grupo de alunos que pretenda participar, independentemente das suas características educacionais, por exemplo ensino regular, cursos profissionais, cursos PIEF, entre outros.

Por outro lado, concluímos ainda que deve existir um enquadramento do projeto com a realidade que pretende dar a conhecer, por exemplo, caso se foque em aspetos legais, a informação passada deve ser a que se encontra em vigor nesse período de tempo. Estas particularidades foram tidas em conta no momento da conceção do Programa Empreender na Escola, tal como referida por Imaginário et al. (2014) e é visivelmente reconhecida pelos participantes, embora considerem que a carga burocrática que acarreta seja bastante extensa.

Esta é, de facto, uma das principais limitações apresentadas por este projeto, pelo que em futuras edições os aspetos burocráticos de criação da miniempresa devem ser reduzidos, permanecendo apenas as atividades consideradas como essenciais, nomeadamente a escolha dos produtos a "exportar", a elaboração do catálogo de produtos e a escolha do nome da "empresa". Com esta alteração dá-se resposta às sugestões apresentadas pelos participantes e permite-se que as "empresas" acelerem o seu ritmo de trabalho, possibilitando ainda o início mais atempado da comercialização dos produtos "importados". As questões mais burocráticas da criação de uma empresa podem ser transmitidas aos alunos através de um formato mais teórico e ser entregues, por exemplo, em formato de papel para que possam ser posteriormente consultadas, circunscrevendo desta forma a constituição da "empresa" às questões essenciais e imprescindíveis.

Embora os participantes tenham apontado algumas críticas à metodologia adotada, considera-se que com a implementação das alterações sugeridas serão eliminadas as desvantagens identificadas, pelo que se sugere que se mantenha o regime de parcerias comerciais, emparelhando as miniempresas e procurando fortalecer as relações entre os jovens empreendedores e os professores envolvidos. Aliás, consideramos que a adoção desta metodologia de parcerias comerciais contribuiu de forma eficaz para a aproximação de alunos e escolas, potenciando também a aproximação de professores. Além disso, os resultados obtidos refletem que o envolvimento ativo dos professores na gestão das miniempresas permite igualmente uma aproximação entre os alunos e os professores participantes.

Ademais, no início da implementação de um projeto desta dimensão consideramos que deve existir um momento de apresentação do mesmo a todos os participantes, não só procurando estabelecer relações entre a equipa técnica e os alunos/professores envolvidos, mas também procurando fomentar o desenvolvimento de uma relação entre os participantes. Sendo o estabelecimento de relações interpessoais um dos aspetos positivos mais referidos pelos participantes considera-se que seria uma mais-valia a realização de um evento de arranque que contasse com a participação de todos os intervenientes e onde fossem distribuídos os materiais a ser utilizados e apresentada a metodologia adotada. Nesta sessão deve ainda ser abordada a questão do capital social inicial da "empresa" para que possam ser esclarecidas quaisquer dúvidas e para que os jovens empreendedores decidam como o pretendem obter.

A recolha e análise das opiniões dos participantes é, em nosso entender, fundamental para compre- 
ender quais os aspetos que devem ser eliminados, melhorados ou mantidos, procurando ultrapassar as desvantagens identificadas neste projeto. Em suma, considera-se que no desenvolvimento de programas de educação para o empreendedorismo, quer seja uma nova edição deste programa, ou não, deve ter-se em conta os aspetos aqui identificados e refletir-se sobre eles.

Embora este trabalho não se debruce sobre a aquisição de conhecimentos ou competências por parte dos participantes, seria uma mais-valia poder proceder a essa análise, pois poderá levantar importantes pistas que possam ser tidas em conta no momento de construir um programa de educação para o empreendedorismo. Sugere-se, assim, que na avaliação de um projeto deste género se proceda igualmente a uma recolha de opiniões, mas que também se tenha em consideração as próprias competências de alunos e professores, incluindo um processo de avaliação multifacetado que deverá contar com pré e pós-teste, assim como grupo de controlo, analisando ainda os comportamentos adotados pelos participantes na gestão das suas miniempresas.

\section{Agradecimentos}

A todos os alunos e professores que participaram no Programa Empreender na Escola, bem como ao município de Sines, ao Sines Tecnopolo e à Universidade do Algarve.

A publicação deste artigo contou com o apoio da instituição portuguesa de financiamento FCT (Fundação para a Ciência e Tecnologia) através da atribuição da Bolsa de Doutoramento número SFRH/BD/76044/2011.

\section{Referências}

Bardin, L. (1995). Análise de conteúdo. Lisboa: Edições 70.

Chaves, R. R. \& Parente, C. (2011). O empreendedorismo na escola e o paradigma das competên- cias: O caso da Junior Achievement - Portugal. Sociologia, Problemas e Práticas, 67, 65-84.

Chong, L. L. et al. (2008). Innovative educational program: A new edge of education. Journal of Applied Sciences, 8(10), 1 832-1 840.

Comissão Europeia (2002). Final report of the expert group "Best Procedure" Project on Education and Training for Entrepreneurship. Bruxelas: Direção-Geral das Empresas da Comissão Europeia.

Centro Promotor de Inovação e Negócios do Algarve (CPINAL) (2002). Manual do aluno: Guia para a elaboração do plano de negócios. Olhão: CPINAL.

Cristo, E., Imaginário, S., \& Cruz, A. L. (Eds.) (2012a). Programa Empreender na EscolaManual do professor. Faro: Universidade do Algarve.

Cristo, E., Imaginário, S., \& Cruz, A. L. (Eds.) (2012b). Programa Empreender na EscolaManual do aluno. Faro: Universidade do Algarve.

Cropley, A. J. (2009). Creativity in education and learning - A guide for teachers and educators. New York: Routledge Falmer.

Csikszentmihalyi, M. (2006). Developing creativity. In N. Jackson, M. Oliver, M. Shaw, \& J. Wisdom (Orgs.), Developing creativity in higher education: An imaginative curriculum (pp. XVIII-XX). London: Routledge.

Cunningham, J. \& Lischeron, J. (1991). Defining entrepreneurship. Journal of Small Business Management, 29(1), 45-61.

Direção-Geral de Inovação e Desenvolvimento Curricular do Ministério da Educação (2009). Relatório síntese do Projeto Nacional "Educação para o Empreendedorismo”. Lisboa: Direção-Geral de Inovação e Desenvolvimento Curricular do Ministério da Educação.

Faria, M. C. (2010). Questionário de Competências Empreendedoras (QCE): Aplicação a estudantes do ensino superior. In L. S. Almeida, B. D. Silva, \& S. Caires (Eds.), Actas do I Seminário 
Internacional "Contributos da Psicologia em Contextos Educativos” (pp. 287-301). Braga: Universidade do Minho.

Garavan, T. \& O'Cinneide, B. (1994). Entrepreneurship education and training programmes: A review and evaluation - Part 1. Journal of European Industrial Training, 18(8), 3-12.

Graevenitz, G., Harhoff, D., \& Weber, R. (2010). The effects of entrepreneurship education. Journal of Economic Behavior \& Organization, 76, 90-112.

Imaginário, S., Cristo, E., Jesus, S. N., \& Morais, F. (2014). Educação para o empreendedorismo em Portugal: O nascimento do Programa Empreender na Escola. Amazônica. Revista de Psicopedagogia Escolar e Educação, 7(2), 343-362.

Jesus, S. N., Nave, F., Gonçalves, L., Caleça, P., \& Oliveira, M. (2011). Intervenções para a promoção do bem-estar e sucesso dos alunos. $\mathrm{O}$ caso do Agrupamento João da Rosa. Amazônica. Revista de Psicopedagogia, Psicologia Escolar e Educação, 7, 107-117.

MacLaren, I. (2012). The contradictions of policy and practice: creativity in higher education. London Review of Education, 10, 159-172.

Matin, B., McNally, J., \& Kay, M. (2013). Examining the formation of human capital in entrepreneurship: A meta-analysis of entrepreneurship education outcomes. Journal of Business Venturing, 28, 211-224.

Mendes, A. R. (2007). Apontamentos sobre a educação para o empreendedorismo em Portugal. Revista Portuguesa de Pedagogia, 41(3), 285-298.

Ministério da Educação (2007). Guião "Promoção do Empreendedorismo na Escola". Lisboa: Ministério da Educação/Direção-Geral de Inovação e Desenvolvimento Curricular.

Moreland, N. (2006). Entrepreneurship and higher education: An employability perspective. Lear- ning \& employability - Series one. York: The Higher Education Academy.

Parque de Ciência e Tecnologia da Covilhã, SA (Parkurbis) (2007). B-Tech: Empresários na Escola - Percursos de acompanhamento à criação de novas empresas de base tecnológica. Covilhã: Parque de Ciência e Tecnologia da Covilhã, SA. Redford, D. (2006). Entrepreneurship education in Portugal: 2004/2005. Comportamento Organizacional e Gestão, 12(1), 19-41.

Redford, D. (2013). A criação de uma estratégia nacional para a educação do empreendedorismo em Portugal. In D. Redford (Ed.), Handbook de educação em empreendedorismo no contexto português (pp. 31-62). Porto: Universidade Católica Editora.

Rocha, A., Silva, M. J., \& Simões, J. (2012). Intenções Empreendedoras dos Estudantes do Ensino Secundário - O Caso do Programa de Empreendedorismo na Escola. Economia Global e Gestão, 17, 77-97.

Rodrigues, R., Dinis, A., Paço, A., Ferreira, J., \& Raposo, M. (2012). The effect of an entrepreneurial training programme on entrepreneurial traits and intention of secondary students. In T. Burger-Helmchen (Ed.), Entrepreneurship - Born. made and educated (pp. 77-92). Rijeka: InTech.

Runco, M. A. (2007). Creativity: Theories and themes, research, development and practice. London: Elsevier Academic Press.

Teixeira, C. (2012). Educação para o empreendedorismo - Um estudo sobre o Projeto Nacional de Educação para o Empreendedorismo. Tese de mestrado não publicada. Universidade de Coimbra, Coimbra, Portugal.

\section{Recebido: março 25, 2015 Aprovado: fevereiro 5, 2016}

